\title{
PROGRESS OF PRADHAN MANTRI JAN DHAN YOJANA (PMJDY): A NATIONAL MISSION FOR FINANCIAL INCLUSION IN INDIA
}

\section{BHOIRAB JYOTI KONCH ${ }^{1} \&$ CHIRANJIB HAZARIKA ${ }^{2}$}

${ }^{1}$ Scholar, Department of Economics, Rajiv Gandhi University, Itanagar, Arunachal Pradesh, India

${ }^{2}$ Scholar, Department of Economics, Mahapurusha Srimanta Sankaradev Viswavidyalaya, Nagaon, Assam, India

\begin{abstract}
Financial inclusion is one amongst the great mission for inclusive growth. It is the accessibility of financial service like savings, insurance, credit and payment facilities to the underprivileged section of the populace. The present paper contextualises the biggest Mission that was introduced by Prime Minister on 15 August, 2014, namely, Pradhan Mantri Jan DhanYojana (PMJDY). This paper, also, attempts the Progress made so far with respect to PMJDY in the recent context. It is found that successfully implementation of the scheme included 92 percent of households in India. Also, it successfully increased in rural areas, particularly, due to inclusion of rural womenfolk through SHGs.

KEYWORDS: Financial Inclusion, Pradhan Mantri Jan DhanYojana, India, Inclusive Growth, SHGs \& Rural Development and Financial Services
\end{abstract}

Received: Jun 07, 2020; Accepted: Jun 27, 2020; Published: Jul 16, 2020; Paper Id.: IJMPERDJUN2020349

\section{INTRODUCTION}

Financial inclusion is delivery of banking services at an affordable cost. As banking services are in the nature of public good, it is essential that banking services be provided indiscriminately to the population. Although credit is the most important component, financial inclusion also covers various financial services such as savings, insurance, payments and remittances (Mahendra S, 2006). Recently, the government of India announced "PradhanMantri Jan DhanYojana" a national mission for financial inclusion; for the growth of rural income by generating employment through the demand of rural people of various services like home loan, education loan, crop loan remittance services. The mission aimed to provide banking facilities to, at least, 75 million people by January, 2015. The PMJDY has been implemented and executed by banks successfully. Thus, as against the estimated target of opening 10 crore accounts, as on 28October, 2015, 19.02 crore accounts have been opened.Outof it about 11.58 crore were with respect to rural areas and about 7.44 crore in urban areas. Deposits of about $\square 25913.55$ crore wasmobilized and about 16.37 crore RuPay Debit cards were issued and Aadhaar sending has been done for about 8 crore accounts holders.

\section{OBJECTIVE OF THE STUDY}

The objective of the study is to analyse and examine the progress of the most ambitious financial inclusion mission in India, namely, PradhanMantri Jan DhanYojana (PMJDY hereafter) 


\section{DATABASE AND METHODOLOGY}

The present study is based only on secondary data. The data was collected from PMJDY website (https://pmjdy.gov.in/). Also, data were collected from published reports, articles and journals. After gathering the required data and provisioning for concordance for compatibility. Using bar diagram and graph plot, analysis is carried out, thereafter, to compare various year on year data examine the progress.

\section{REVIEW OF LITERATURE}

There exists pool of literature with respect to PMJDY. While many are studies pertaining to disaggregated micro context state or region specific - or else there are aggregated macro for the nation, thereby, not giving much clarity on the progress of the mission. In fact, other than the macro reports of the concerned ministry taking up the mission, few independent authors have evaluated the mission, but in piecemeal approach, for instance, C. Singh and G. Naik (2018), P. S. Senapati, (2018), P. K. Nimbrayan, N. Tanwar, and R. Tripathi (2018), N. Kholi (2013), C. Rangarajan (208) and S.S. Singh, and J. P. Pande (2014) and so forth.

\section{RESULTS AND DISCUSSIONS}

Financial inclusion is one universal mission to boost the usages of banking services for eradication of poverty. For the purpose, Government of India has launch of PMJDY. The scheme is not just to create bank accounts but also to provide some basic advantages like zero balance bank account along with issue of RuPay debit card against the account, to cover accidental insurance of 1 (one) lakh for the account holderwho opened the same on or before of the 26 day of January, 2015. Consequent upon it was the Direct Benefit Transfer (DBT hereafter) scheme wherein benefit like remittance, wages, subsidies etc., from Government were directly linked and benefits deposited directly to the beneficiary'sbank account. The main thrust of the Government's move is to provide, at least, onebank account to every household.

\subsection{The Objectives of PMJDY}

PMJY has been implemented, keeping in backdrop, the following basic objectives:

- Universal access to banking facilities.

- $\quad$ Banking accounts with RuPay debit card with the provision of overdraft facility.

- $\quad$ Financial literacy programme.

- Creation of credit guarantee fund.

- Micro finance.

\subsection{The Benefits given by PMJDY Scheme}

Based on the basic objective, as a sequel, it is expected that PMJDY will provides some special benefits to the beneficiary. These are:

- Interest on deposit.

- Accidental insurance cover of $\square 2$ lakhs.

- No minimum balance required. 
- It provides life cover of $\square 30,000$ payable of death of the beneficiary, subject to fulfilment of the eligibility condition.

- Easy transfer of money across India.

- Beneficiaries of Government schemes will get DBT (Direct Benefit Transfer) in these accounts.

- After satisfactory operation of the account for 6 (six) months, an overdraft facility will be permitted.

- Access to pension, insurance and welfare prducts.

- The claim under Personal Accidental Insurance under PMJDY shall be payable if the RuPay card holder have performed minimum one successful financial or non-financial customer induced transaction at any Bank Branch, Bank Mitra, ATM, POS, E-COM etc. channel both Intra and Inter-bank within 90 days prior to date of accident including accident date will be included as eligible transactions under the RuPay insurance Program 2019-2020.

- Overdraft facility upto $\square 10,000$ is available in only one account per household, preferable lady of the household.

\section{PROGRESS OF PMJDY}

The scheme was launch in 2014, since 2014 to 2020 numbers of accounts opened are increasing continuously day by day. A two point comparison is made in table 1 and table 2 to cross examine the progress The progress of PMJDY can be explained with the help of table 1.

Table 1: Status of PMJDY (Account Open as on 04/02/2015)

\begin{tabular}{|l|c|c|c|c|c|}
\hline $\begin{array}{l}\text { Bank Name } \\
\text { /Type }\end{array}$ & $\begin{array}{c}\text { Rural/ Semi } \\
\text { Urban }\end{array}$ & $\begin{array}{c}\text { Urban/ } \\
\text { Metro }\end{array}$ & $\begin{array}{c}\text { No. of Total } \\
\text { Beneficiaries }\end{array}$ & $\begin{array}{c}\text { Deposits in } \\
\text { Accounts (in Lakh) }\end{array}$ & $\begin{array}{c}\text { No. of Rupay Debit Card } \\
\text { Issued To Benificiares }\end{array}$ \\
\hline $\begin{array}{l}\text { Public sector } \\
\text { bank }\end{array}$ & 54018407 & 45748043 & 99766450 & 834558.63 & 92423911 \\
\hline RRB & 18756918 & 3335820 & 22092738 & 164641.52 & 15246580 \\
\hline $\begin{array}{l}\text { Private sector } \\
\text { bank }\end{array}$ & 3253732 & 2036082 & 5289814 & 72109.39 & 4606243 \\
\hline \multicolumn{7}{|l|}{ Total } & $\mathbf{7 6 0 2 9 0 5 7}$ & $\mathbf{5 1 1 1 9 9 4 5}$ & $\mathbf{1 2 7 1 4 9 0 0 2}$ & $\mathbf{1 0 7 1 3 0 9 . 5 4}$ & $\mathbf{1 1 2 2 7 6 7 3 4}$ \\
\hline \multicolumn{7}{|l}{ Source: PMJDY website. (https://pmjdy.gov.in/) } \\
\hline
\end{tabular}

In Table 1, the category wise distribution of total accounts opened in bank categories with the rural and urban break is given along with the total number of RuPay debit card issued by bank to beneficiaries. It is evidentthat the total account opened is more in the Public Sector bank (99766450Accounts) with a deposit of $\square 34558.63$ lakh. The Public Sector banks alsoissued about 92423911 numbers of RuPay debit card to its beneficiaries. This is followed by the RRB, wherein about 22092738 accounts were opened with a deposit of $\square 164641.52$ lakh. The total number of RuPay debit card issued is about 15246580.The Private Sector bank, although last in the hierarchy, too opened about 5289814 accounts under PMJDFY against which about 4606243 RuPay debit card were issued and with a deposits of $\square 72109.39$ lakh.

Table 2: Status of PMJDY (Account Opened as on 12/02/2020)

\begin{tabular}{|l|c|c|c|c|c|}
\hline $\begin{array}{l}\text { Bank Name } \\
\text { /Type }\end{array}$ & $\begin{array}{c}\text { Rural/ Semi } \\
\text { Urban }\end{array}$ & $\begin{array}{c}\text { Urban/ } \\
\text { Metro }\end{array}$ & $\begin{array}{c}\text { No. of Total } \\
\text { Beneficiaries }\end{array}$ & $\begin{array}{c}\text { Deposites in } \\
\text { Accounts (in Lakh) }\end{array}$ & $\begin{array}{c}\text { No. of RuPay Debit } \\
\text { Card Issued to } \\
\text { Benificiares }\end{array}$ \\
\hline $\begin{array}{l}\text { Public } \\
\text { sector bank }\end{array}$ & 163480640 & 139503409 & 302984049 & 9110248.99 & 243998742 \\
\hline RRB & 52658040 & 12404213 & 65062253 & 2100209.93 & 35619051 \\
\hline
\end{tabular}




\begin{tabular}{|l|c|c|c|c|c|}
\hline $\begin{array}{l}\text { Private } \\
\text { sector bank }\end{array}$ & 6983207 & 5575487 & 12558694 & 317209.98 & 11525143 \\
\hline \multicolumn{1}{|l|}{ Total } & $\mathbf{2 2 3 1 2 1 8 8 7}$ & $\mathbf{1 5 7 4 8 3 1 0 9}$ & $\mathbf{3 8 0 6 0 4 9 9 6}$ & $\mathbf{1 1 5 2 7 6 6 8 . 9}$ & $\mathbf{2 9 0 8 4 2 9 3 6}$ \\
\hline
\end{tabular}

A similar analysis is considered at table 2 for different time point for the status of PMJDY i.e. as on 12/02/2020. Evidently, the trend is similar as in previous analysis but it is indicative of a rapid increase in the opening of new account with higher deposits and issue of more RuPay debit card to the beneficiaries in both rural and urban areas of India. The total accounts opened in Public Sector bank increased to 302984049 with a deposit of 9110248.99 lakh and issue of RuPay debit card to 243998742. Similarly, it is followed by RRB, whereby new accounts increased to 65062253 with larger deposits of 2100209.93 lakh and more of RuPay debit card being issued; about 35619051. Follower by private bank increases to 12558694 account with deposits of 317209.98 lakh and provide 11525143 RuPay debit card to the beneficiaries.

Table 3: Progress of PMJDY by Bank wise in Total of Various Years

\begin{tabular}{|l|l|l|l|l|l|l|}
\hline \multicolumn{1}{|r|}{ Years } & $\begin{array}{c}\text { Number of } \\
\text { Total } \\
\text { Beneficiaries }\end{array}$ & $\begin{array}{c}\text { Growth Rate } \\
\text { Number of } \\
\text { Account (in } \\
\text { \%) }\end{array}$ & $\begin{array}{c}\text { Deposits in } \\
\text { Account (in } \\
\text { Lakh) }\end{array}$ & $\begin{array}{c}\text { Growth Rate } \\
\text { Deposits (in } \\
\% \text { ) }\end{array}$ & $\begin{array}{c}\text { Number of } \\
\text { RuPay Debit } \\
\text { Card }\end{array}$ & $\begin{array}{c}\text { Growth } \\
\text { Rate of } \\
\text { RuPay } \\
\text { Debit Card } \\
\text { (in \%) }\end{array}$ \\
\hline $8 / 10 / 2014$ & 29865809 & - & 13532.77 & - & 14555609 & - \\
\hline $4 / 2 / 2015$ & 127149002 & 76.51 & 1071309.54 & 98.74 & 112276734 & 87.04 \\
\hline $3 / 2 / 2016$ & 206283942 & 38.36 & 3139966.99 & 65.88 & 172647705 & 34.97 \\
\hline $1 / 2 / 2017$ & 273933371 & 24.70 & 6649164.39 & 52.78 & 214771385 & 19.61 \\
\hline $7 / 2 / 2018$ & 310724573 & 11.84 & 7453478.87 & 10.79 & 234353455 & 8.36 \\
\hline $13 / 02 / 2019$ & 344274123 & 9.75 & 9114194.8 & 18.22 & 273570167 & 14.34 \\
\hline $12 / 2 / 2020$ & 380604996 & 9.55 & 11527668.9 & 20.94 & 290842936 & 5.94 \\
\hline
\end{tabular}

Table 3, gives a clearer picture of progress in PMJDY scheme of various components and on year on year basis. With respect to total number of accounts opened, the overall increase was 92 percent for the period 2014 to 2020 respectively. But if we see the growth rate year by year it slightly decreased from 77 percent in 2014 to 10 percent 2020 . Similarly, deposits in accounts also decreased from 99 percent in 2014 to 21 percent in 2020. The Growth rate of number of RuPay debit card also decreased from 87 percent to 6 percent in 2020. Incase of absolute coverage, however, the numbers is increasingtremendously in all the aspect for all the banks. The growth rate of beneficiaries, growth rate of deposits and growth rate of RuPay debit card is shown in the following chart. 


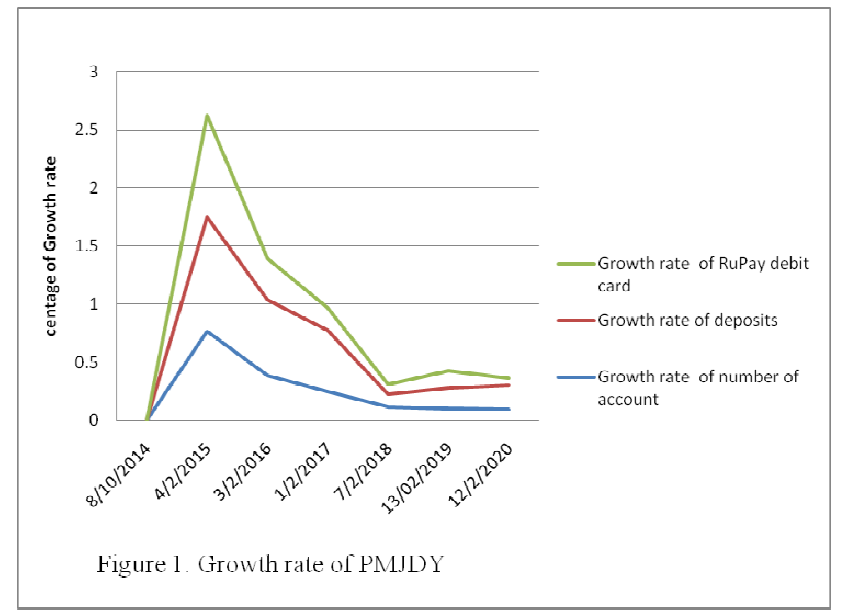

It is clear from the above chart the various aspect of PMJDY bank progress year by year has been declining, but from the beginning of PMJDY to 2020 it increased. This is obvious to decline as more and more coverage takes place. .

\section{LIMITING FACTORS PMJDY}

With PMJDY a large numbers of accountswere opened and so long as coverage is concerned it seems successful execution of the mission. However, certain qualitative factors hinder the successful implementation of the scheme. As such, it is not free from weakness. The following drawbacks act as hindrance in the implementation of the scheme.

- The issue of multiple accounts.

- Infrastructural issues

- Lack of awareness

- Inactive account

- Less availability of ATMs in rural areas

- Confusion regarding the validity of insurance claims.

\section{CONCLUSIONS}

The Pradhan Mantri Jan DhanYojana has provided basic banking facility to the unbendable section of the society. It helps in the financial inclusion and enhances the inclusive growth of the country. There were many financial inclusion policy prior to the PMJDY, but not as successful as it is. Successful execution and implementation by taking the mission as high priority have resulted in nearly 92 percent of the households in India to have bank accounts with debit card facilities. This scheme is more successful in rural areas due to inclusion of rural women through self help groups to provide direct benefit transfer from the Government. Till date, the PMJDY has registered outstanding performance and helps towards the goal of absolute financial inclusion in India.

\section{REFERENCES}

1. C. Singh and G. Naik, "Financial Inclusion after PMJDY” IIBM-Working Paper, 2018, 568 
2. P. S. Senapati, “ A study of Pradhan Mantri Jan DhanYojana (PMJDY) Scheme in Odisha and Challenges of Financial inclusion” International Journal of Research in Humanities, Arts and Literature, ISSN (P): 2347-4564; ISSN (E): 2321-8878, Vol. 6, Issue 3, March 2018, pp. 155-160

3. Gupta, Sapana, and K. S. Thakur. "Performance Evaluation of Financial Inclusion in India: With Special Reference to Pradhan Mantri Jan DhanYojana (PMJDY)."

4. P. K. Nimbrayan, et al., "Pradhan Mantri Jan DhanYojana (PMJDY): The Biggest Financial Inclusion Initiative in the world”, ISSN: 0976-4666, Economic affairs, Vol. 63, No. 2, June 2018, pp. 583-590 New Delhi Publishers.

5. Raj, Sonia. "Problems Faced by Entrepreneurs: A Special Reference to Micro and Small Entrepreneurs in Mumbai and Pune." International Journal of Business Management \& Research (IJBMR) ISSN (P) (2016): 2249-6920.

6. N. Kholi, “Financial Inclusion \& Impact Banking Sector in India”. Tecnia Journal of Management Studies, 2013.

7. C. Rangarajan, “Report of Financial Inclusion”, 2008, 1-31, Govt. of India.

8. Jindal, Neena, Kritika Thakur, and Tania Sharma. "Digital India: Challenges, Solutions and its Impact on Society. "International Journal of Environment, Ecology, Family and Urban Studies (IJEEFUS) 9. 2, Apr 2019, 83-90

9. S.S. Singh, and P. J. Pande, “PradhanMantri Jan DhanYojana: A Giant Leap Towards Financial Inclusion”. International Journal of Research in Management and Business Studies, 1(4): 19-22, 2014.

10. Bhasin, Supriya, and SS Dhami. "Business Process Reengineering-The Role of Human Resource Function: A Comprehensive Review of Literature. "International Journal of Business Management \& Research (IJBMR) 8. 4, Aug 2018, 1-18

11. https://pmjdy.gov.in/

12. Other various websites, Journals, magazines etc. 